\title{
THE PECULIARITIES OF CALCULATION AND RECORDING IN ACCOUNTING ASSISTANCE OF TEMPORARY DISABILITY DURING 2015 AND THE PROSPECT OF FURTHER REFORMING SOCIAL SECURITY IN UKRAINE
}

\author{
Yanina NIKITINA ${ }^{1}$, \\ Ivan Franko State University of Lviv, Ukraine
}

\begin{abstract}
The aim is to investigate the influence of legislative changes on the process of calculation of temporary disability and reflection of such transactions on accounts of bookkeeping with the aim to predict future directions of development and formation the system of social insurance for temporary disability in Ukraine. The method of data analysis on the amount of financial support when there is the temporary disability with regard to various legal conditions made it possible to research the consequences of the implementation of certain regulations. Methodology of the research is made through comparison of the size of financial compensation when the insurance case happen in three different legally controlled conditions that varied in Ukraine during the current 2015. The results are represented with linear schedule. Results of the research show the reasons and economic consequences of implementation of existing legislation of July 4, 2015 and enable to predict future changes on the way of establishing the uniform rules of social insurance for temporary disability and implementing health insurance in Ukraine. The main directions of possible reforms in refund of lost earnings were also considered. In particular, there is an example of reflection of insurance case and the loss of efficiency calculation aid through case study. Today the social insurance system in Ukraine undergoes significant changes with the aim to improve and adapt to global trends. Implementation of accounting various areas and spheres undergoes constant change towards optimization ensuring compliance with the basic principles of accounting, better reflection and recording accounting events, consistency and clarity of registration credentials, transparency and simplification of calculation and charging of various accounting indicators. The practical significance of the research is the detailed description of the process of calculating financial aid from the temporary disability depending on length of service employee, and display of the received sums of money on accounts in different periods in 2015. Value/originality. The results of this research allow to structure accounting information according to the process of calculating monetary aid on disability and create a basis for further researches and prolonging reforms of social security in Ukraine, according to proposed directions.
\end{abstract}

Key words: accounting of financial support, average wage, charges aid, insured person, the normative legal regulation, social insurance.

JEL Classification: M41, H55, K3

\section{1. Введение}

С 1 января 2015 были внесены изменения в Закон Украины «Об общеобязательном государственном социальном страховании» № 1105 (Аалее - Закон № 1105), на основании которых утратил силу Закон Украины «Об общеобязательном государственном социальном страховании в связи с временной потерей трудоспособности и расходами, обусловленными погребением» № 2240 (Аалее - Закон № 2240). С 26 июня 2015 был принят в новой реАакции, аАаптированный с Законом № 1105, Порядок оплаты первых пяти Аней временной нетрудоспособности вслеАствие заболе- вания или травмы, не связанной с несчастным случаем на производстве, за счет среАств работодате я№ 440 (АалееПорядок № 440). А с 04.07.2015 вступило в силу Постановмение Кабинета Министров Украины от 26.06.2015 № 439, согласно которому были внесены изменения в Постановление Кабинета министров Украины об исчисмении средней заработной пиаты (Аохода, денежного обеспечения) Аля расчета выплат по общеобязательному государственному социальному страхованию № 1266 от 26.09.2001 (Аалее - Постановление № 1266), в результате чего был изменен порядок начисления больничных и декретных выплат работникам.

Corresponding author:

${ }^{1}$ Department of Accounting and Audit, Ivan Franko State University Lviv.

E-mail: Janochka7@gmail.com 
Реформирование системы социального страхования в Украине продолжается. Целью Аанного исследования явмяется анализ текущих изменений процесса учета и прогноз будущих нововвеАений. Основными научно-исследовательскими задачами явмяется расчет размера пособия в связи с наступлением страхового случая Аля работника, если мисток нетрудоспособности был выдан Ао 01.01.2015 года; расчет материального обеспечения Аля страхового скучая, наступившего после 01.01.2015, а также посме 04.07.2015; отображение описанных бухгалтерских операций на счетах учёта; анализ размера полученного материального обеспечения и отображения полученных Аанных с помощью графика; описание, начисление и учет наступления страхового случая во время слеАующих этапов реформирования системы социального страхования в Украине.

\section{2. Анализ нормативно-правового регумирования социального страхования в Украине}

В связи с изменением нормативно-правовых актов по урегулированию сферы социального страхования, возник ряА особенностей по исчислению пособия по временной нетрудоспособности.

Статьей 24 Закона № 1105 с 1 января 2015 изменен размер пособия по временной нетрудоспособности в зависимости от страхового стажа. Пособие по временной нетрудоспособности выплачивается застрахованным лицам в зависимости от страхового стажа в следующих размерах:

1) 50 процентов средней заработной платы (Аохода) застрахованным мицам, имеющим страховой стаж Ао трех мет;

2) 60 процентов средней заработной платы (Аохода) застрахованным мицам, имеющим страховой стаж от трех до пяти мет;

3) 70 процентов среАней заработной пиаты (Аохода) застрахованным кицам, имеющим страховой стаж от пяти Ао восьми мет;

4) 100 процентов среАней заработной платы (Аохода) застрахованным иицам, имеющим страховой стаж более восьми мет (Закон № 1105).
Опиата первых пяти Аней временной нетрудоспособности вслеАствие заболевания или травмы, не связанной с несчастным случаем на производстве, осуществцялась за счет среАств работодателя в соответствии с Постановлением № 439. То есть до 26 июня 2015 принимали во внимание размер рассчитанной суммы в соответствии со страховым стажем в размере $60 \%$ (Ао 5 мет), $80 \%$ (от 5 Ао 8 мет) или 100\% (более 8 мет). 26 июня 2015 было принято Постановление 440, в соответствии с которым расчет первых 5 Аней нетрудоспособности за счёт средств работодателя, осуществляется с учетом процентов страхового стажа в соответствии с ПоряАком № 1266.

Сравнение предылущего и нового порядка учета величины стажа при расчете материального обеспечения по временной нетрудоспособности отразим с помощью таблицы 1 «Зависимость пособия по временной нетрудоспособности от величины страхового стажа».

На рисунке 1 «Сравнение зависимости размера материального обеспечения от векичины страхового стажа Ао и после 01.01.2015» виАно, что внеАрение Закона № 1105 преАусматривает также сокращение расхоАов ФонАа на финансирование пособий по временной нетрудоспособности.

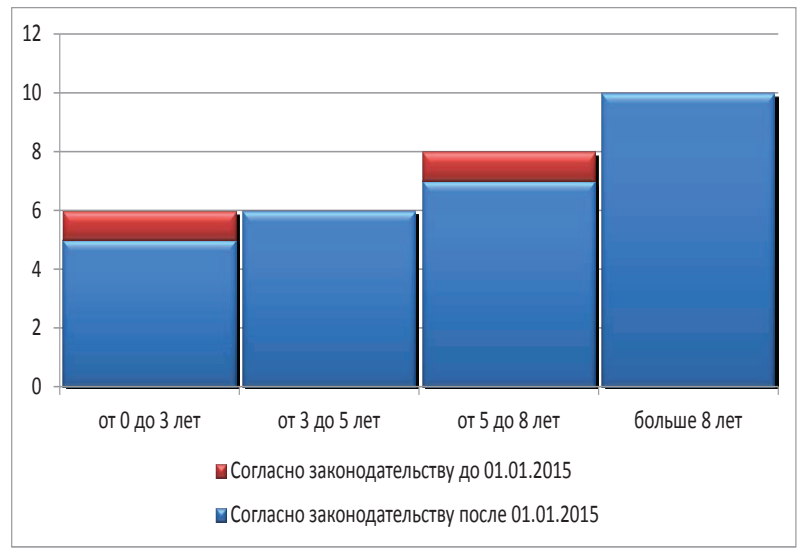

Рис. 1. Сравнение зависимости размера материального обеспечения от векичины страхового стажа Ао и после 01.01.2015

Таблица 1

Зависимость пособия по временной нетрудоспособности от вемичины страхового стажа

\begin{tabular}{|c|c|c|c|c|c|c|c|}
\hline № & $\begin{array}{c}\text { Аля } \\
\text { страхового } \\
\text { случая }\end{array}$ & $\begin{array}{c}\text { ПреАвиАится } \\
\text { правовыми актами }\end{array}$ & Оплачивает & стаж до 3 мет & 3-5 «ет & 5-8 ^ет & Больше 8 мет \\
\hline \multirow[b]{2}{*}{1.} & \multirow[b]{2}{*}{ Aо 01.01.2015 } & \multirow[b]{2}{*}{$\begin{array}{c}\text { Закон } 2240 \\
\text { Постановцение } 439 \\
\text { Порядок } 1266\end{array}$} & Работодатемь & $60 \%$ & $60 \%$ & $80 \%$ & $100 \%$ \\
\hline & & & $\begin{array}{c}\text { ФонА социального } \\
\text { страхования с временной } \\
\text { нетрудоспособности }\end{array}$ & $60 \%$ & $60 \%$ & $80 \%$ & $100 \%$ \\
\hline \multirow[b]{2}{*}{2.} & \multirow{2}{*}{$\begin{array}{l}\text { от 01.01.2015 } \\
\text { Ао 26.06.2015 }\end{array}$} & \multirow{2}{*}{$\begin{array}{c}\text { Закон } 1105 \\
\text { Постановмение } 439 \\
\text { Порядок } 1266\end{array}$} & Работодатемь & $60 \%$ & $60 \%$ & $80 \%$ & $100 \%$ \\
\hline & & & $\begin{array}{c}\text { Фона социального } \\
\text { страхования }\end{array}$ & $50 \%$ & $60 \%$ & $70 \%$ & $100 \%$ \\
\hline \multirow[b]{2}{*}{3.} & \multirow[b]{2}{*}{ от 26.06.2015 } & \multirow{2}{*}{$\begin{array}{c}\text { Закон } 1105 \\
\text { Постановмение } 440 \\
\text { Порядок } 1266\end{array}$} & Работодатель & $50 \%$ & $60 \%$ & $70 \%$ & $100 \%$ \\
\hline & & & $\begin{array}{c}\text { ФонА социального } \\
\text { страхования }\end{array}$ & $50 \%$ & $60 \%$ & $70 \%$ & $100 \%$ \\
\hline
\end{tabular}




\section{3. Процесс начисления и учета материамьного обеспечения AO 04.07.2015 гоAа}

Рассмотрим, как меняется размер пособия по временной нетрудоспособности в связи с изменениями законодательных норм. Рассмотрим эти изменения на примере. Предположим, что при прочих равных условиях работник отдела сбыта в организации получает ежемесячно 2500 грн. в течение последних 12 месяцев. Период отпуска был в августе 2014 года. Работник забомел и обратился в местную поликлинику. Ему выдали Аисток нетрудоспособности на периоА с 02 июмя по 15 июля. Рассчитаем размер пособия, причитающегося работнику за такой период нетрудоспособности.

1. Рассчитаем размер среднедневного пособия Аля такого работника: Аля этого сумму заработной платы за последние полные 6 месяцев поделим на количество отработанных дней в периоде. Расчет преАставим с помощью таблицы 2 «Расчет среАнеАневной заработной платы Аля работника».

Таблица 2

Расчет среднеАневной заработной пиаты Аля работника

\begin{tabular}{|l|c|c|c|}
\hline Месяц & $\begin{array}{c}\text { ОклаА (согласно } \\
\text { отработанному } \\
\text { времени), грн. }\end{array}$ & $\begin{array}{c}\text { Количество } \\
\text { рабочих } \\
\text { Аней }\end{array}$ & $\begin{array}{c}\text { Количество } \\
\text { отработанных } \\
\text { рабочих Аней в } \\
\text { месяце }\end{array}$ \\
\hline Июнь & 2500 & 20 & 20 \\
\hline Май & 2500 & 18 & 18 \\
\hline Апремь & 2500 & 21 & 21 \\
\hline Март & 2500 & 21 & 21 \\
\hline Феврамь & 2500 & 20 & 20 \\
\hline Январь & 2500 & 20 & 20 \\
\hline Сумма & 15000 & $\mathrm{X}$ & 120 \\
\hline
\end{tabular}

Рассчитываем среднедневную заработную плату: $15000 / 120=125$ грн.

2. Теперь определим размер помощи за весь периоА нетрудоспособности. Аия этого нужно размер среАнеАневной зарплаты умножить на количество рабочих Аней в периоде нетрудоспособности. Рабочие Ани с пяти первых календарных оплачиваются за счет среАств предприятия (организации, учреждения), остальные Ани нетрудоспособности в пределах 4 месяцев опиачивает ФонА социального страхования (Ао 01.01.2015 - ФонА социального страхования по временной потере трудоспособности).

Размер помощи за весь период нетрудоспособности составит: 125 грн. ${ }^{*} 10$ рабочих Аней $=1250$ грн. Если стаж работника составцяет более 8 мет, начисмяем 100\% от исчисленной суммы.

3. Таким образом, 3 рабочих дня оплачиваются за счетов среАств предприятия и 7 за счет Фонда. Это составмяет 375 грн. и 875 грн. соответственно. Отразим эти операции на счетах бухгалтерского учета - таблица 3 «КорреспонАенция счетов по начислению пособия по временной нетрудоспособности».
Таблица 3

Корреспонденция счетов по начислению пособия по временной нетрудоспособности

\begin{tabular}{|c|c|c|c|c|}
\hline № & Бухгалтерская операция & $\mathrm{AT}_{\mathrm{T}}$ & $\mathrm{KT}_{\mathrm{T}}$ & Сумма \\
\hline \multirow[t]{3}{*}{1.} & Начисление: & & & \\
\hline & Пособие за счёт работодателя & 93 & 663 & 375,00 \\
\hline & $\begin{array}{l}\text { Пособие за счёт ФонАа } \\
\text { социального страхования }\end{array}$ & 378 & 663 & 875,00 \\
\hline \multirow[t]{3}{*}{2.} & УАержаний еАинственный взнос: & & & \\
\hline & $\begin{array}{l}\text { С пособия за счёт работодателя } \\
(2 \%)\end{array}$ & 663 & 651 & 7,50 \\
\hline & $\begin{array}{l}\text { С пособия за счёт Фонда } \\
\text { социального страхования (2\%) }\end{array}$ & 663 & 651 & 17,50 \\
\hline \multirow[t]{3}{*}{3.} & УАержанный налог с АохоАа: & & & \\
\hline & $\begin{array}{l}\text { С пособия за счёт работодатемя } \\
(15 \%)\end{array}$ & 663 & 641 & 55,13 \\
\hline & $\begin{array}{l}\text { С пособия за счёт ФонАа } \\
\text { социального страхования (15\%) }\end{array}$ & 663 & 641 & 128,63 \\
\hline \multirow[t]{3}{*}{4.} & УАержанный взнос на оборону: & & & \\
\hline & $\begin{array}{l}\text { С пособия за счёт работодатемя } \\
(1,5 \%)\end{array}$ & 663 & 641 & 5,63 \\
\hline & $\begin{array}{l}\text { С пособия за счёт Фонда } \\
\text { социального страхования }(1,5 \%)\end{array}$ & 663 & 641 & 13,13 \\
\hline 5. & $\begin{array}{l}\text { Выплачено с кассы пособие за } \\
\text { счёт работодатемя }\end{array}$ & 301 & 663 & 306,74 \\
\hline 6. & $\begin{array}{l}\text { На отАельный банковский счёт } \\
\text { пришло пособие от ФонАа } \\
\text { социального страхования }\end{array}$ & 311 & 301 & 875,00 \\
\hline 7. & $\begin{array}{l}\text { Пособие за счет Фонда } \\
\text { социального страхования } \\
\text { выплачено работнику }\end{array}$ & 663 & 378 & 715,74 \\
\hline
\end{tabular}

Если стаж работника составит от 5 до 8 мет, то размер пособия по временной потере трудоспособности составит 70\% от начисленной суммы (Ао 01.01.2015 гоАа 80\%), а именно: 375 грн. ${ }^{*} 0,7=262,50$ грн. (Ао 01.01.2015 года: 375 грн. ${ }^{*} 0,8=300$ грн.) за счет преАприятия (организации, учреждения);

875 грн. ${ }^{*} 0,7=612,50$ грн. (Ао 01.01.2015 года: 875 грн. ${ }^{*} 0,8=700$ грн.) за счет Фонда социального страхования;

1250 грн. ${ }^{*} 0,7=875$ грн. (Ао 01.01.2015 года: 1250 грн. * 0,8 = 1000 грн.) составит общая сумма возмещений по временной потере трудоспособности Аля работника.

Если стаж работника составит от 3 до 5 мет, то размер пособия по временной потере трудоспособности составит $60 \%$ от начисленной суммы (Ао 01.01.2015 гоАа также 60\%), а именно:

375 грн. * 0,6 = 225 грн. (Ао 01.01.2015 года - также 225 грн.) за счет преАприятия (организации, учрежАения);

875 грн. * 0,6 = 525 грн. (Ао 01.01.2015 года - также 525 грн.) за счет Фонда социального страхования;

1250 грн. ${ }^{*}$ 0,6 = 750 грн. (Ао 01.01.2015 года - также 750 грн.) составит общая сумма возмещений по временной потере трудоспособности Аля работника. Если стаж работника составит менее 3 мет, то размер пособия 
по временной потере трудоспособности составит 50\% от начисленной суммы (Ао 01.01.2015 года - 60\%), а именно: 375 грн. * 0,5 = 187,50 грн. (Ао 01.01.2015 года: 375 грн. * 0,6 = 225 грн.) за счет преАприятия (организации, учреждения);

875 грн. ${ }^{*} 0,5=437,50$ грн. (Ао 01.01.2015 года: 875 грн. ${ }^{*} 0,6=525$ грн.) за счет Фонда социального страхования;

1250 грн. * 0,5 = 625 грн. (Ао 01.01.2015 года: 1250 грн. * 0,6 = 750 грн.) составит общая сумма возмещений по временной потере трудоспособности Аля работника.

\section{4. Процесс начисления и учета материамьного обеспечения после 04.07.2015 года}

С 4 июля 2015 вступил в силу Порядок № 1266 в новой редакции, который регумирует процесс начисления и учета пособий по временной нетрудоспособности. Bсе первичные кистки нетрудоспособности, периоА нетруАоспособности по которым начинается после 4 июля 2015, представленные Аля расчёта в бухгалтерию, слеАует рассчитывать в соответствии с новой реАакцией Порядка 1266. Рассмотрим алгоритм расчета материального пособия с помощью ситуативного примера.

ПреАположим, что при прочих равных условиях работник организации получает ежемесячно 2500 грн. в течение последних 12 месяцев. Период отпуска был в августе 2014 года. Работник заболел и обратился в местную поликлинику. Ему выдали мисток нетрудоспособности на периоА с 02 сентября по 15 сентября. Рассчитаем размер пособия, причитающегося работнику за такой периоА нетрудоспособности.

Размер среАнеАневной заработной платы исчисляется путем Аеления совокупной заработной платы за последние полные 12 месяцев, с учетом отпускных, искиючая суммы пособия по временной потере труАоспособности, если такие были в расчётном периоде, на количество календарных Аней в расчетном периоде, включая все выходные и праздничные, без учета Аней нетрудоспособности и неотработанных по уважительным причинам (Постановление № 1266).

1. Рассчитаем размер пособия по временной потере трудоспособности Аля работника, сгруппировав Аанные в таблице 4 «Расчет среАнеАневной заработной платы Аля работника».

Рассчитываем среднеАневную заработную пиату 30 000/365 = 82,19 грн.

2. Теперь определим размер помощи за весь периоА нетрудоспособности. Аця этого нужно размер среАнеАневной зарплаты умножить на количество каленАарных Аней в периоде нетрудоспособности. Первые пять календарных Аней оплачиваются за счет среАств преАприятия (организации, учреждения), остальные Ани нетрудоспособности в пределах 4 месяцев оплачивает ФонА социального страхования.
Таблица 4

Расчет среднеаневной заработной пматы Амя работника

\begin{tabular}{|l|c|c|}
\hline \multicolumn{1}{|c|}{ Месяц } & $\begin{array}{c}\text { ОклаА (согласно } \\
\text { отработанному времени), } \\
\text { грн. }\end{array}$ & $\begin{array}{c}\text { Количество } \\
\text { календарных } \\
\text { Аней }\end{array}$ \\
\hline Август & 2500 & 31 \\
\hline Июль & 2500 & 31 \\
\hline Июнь & 2500 & 30 \\
\hline Май & 2500 & 31 \\
\hline Апремь & 2500 & 30 \\
\hline Март & 2500 & 31 \\
\hline Февраль & 2500 & 28 \\
\hline Январь & 2500 & 31 \\
\hline Аекабрь & 2500 & 31 \\
\hline Ноябрь & 2500 & 30 \\
\hline Октябрь & 2500 & 31 \\
\hline Сентябрь & 2500 & 30 \\
\hline ПІАСуМОК & 30000 & 365 \\
\hline
\end{tabular}

Таблица 5

Корреспонденция счетов по начислению пособия по временной нетруАоспособности

\begin{tabular}{|c|c|c|c|c|}
\hline № & Бухгалтерская операция & $\Delta \mathrm{T}$ & $\mathrm{K}_{\mathrm{T}}$ & Сумма \\
\hline \multirow[t]{3}{*}{1.} & Начисление: & & & \\
\hline & Пособие за счёт работодатемя & 93 & 663 & 410,95 \\
\hline & $\begin{array}{l}\text { Пособие за счёт Фонда } \\
\text { социаиьного страхования }\end{array}$ & 378 & 663 & 739,71 \\
\hline \multirow[t]{3}{*}{2.} & $\begin{array}{c}\text { УАержаний еАинственный } \\
\text { взнос: }\end{array}$ & & & \\
\hline & $\begin{array}{l}\text { С пособия за счёт работодателя } \\
(2 \%)\end{array}$ & 663 & 651 & 8,22 \\
\hline & $\begin{array}{l}\text { С пособия за счёт ФонАа } \\
\text { социального страхования (2\%) }\end{array}$ & 663 & 651 & 14,79 \\
\hline \multirow[t]{3}{*}{3.} & УАержанный налог с Аохода: & & & \\
\hline & $\begin{array}{l}\text { С пособия за счёт работодатемя } \\
(15 \%)\end{array}$ & 663 & 641 & 60,41 \\
\hline & $\begin{array}{l}\text { С пособия за счёт Фонда } \\
\text { социамьного страхования } \\
(15 \%)\end{array}$ & 663 & 641 & 108,74 \\
\hline \multirow[t]{3}{*}{4.} & УАержанный взнос на оборону: & & & \\
\hline & $\begin{array}{l}\text { С пособия за счёт работодатемя } \\
(1,5 \%)\end{array}$ & 663 & 641 & 6,16 \\
\hline & $\begin{array}{l}\text { С пособия за счёт Фонаа } \\
\text { социамьного страхования } \\
(1,5 \%)\end{array}$ & 663 & 641 & 11,10 \\
\hline 5. & $\begin{array}{l}\text { Выпмачено с кассы пособие за } \\
\text { счёт работодателя }\end{array}$ & 301 & 663 & 336,16 \\
\hline 6. & $\begin{array}{l}\text { На отАельный банковский счёт } \\
\text { пришло пособие от ФонАа } \\
\text { социального страхования }\end{array}$ & 311 & 301 & 739,71 \\
\hline 7. & $\begin{array}{l}\text { Пособие за счет Фонда } \\
\text { социального страхования } \\
\text { выпиачено работнику }\end{array}$ & 663 & 378 & 605,08 \\
\hline
\end{tabular}


Размер помощи за весь период нетрудоспособности составит (если страховой стаж более 8 мет):

82,19 грн. * 14 календарных Аней $=1$ 150,66 грн. Из них 410,95 грн. за 5 первых камендарных Аней оплачивает предприятие (организация, учреждение), а остальные 9 календарных Аней - 739,71 грн. - Фонд социального страхования. Отразим эти операции на счетах бухгалтерского учета - таблица 5 «Корреспонденция счетов по начислению пособия по временной нетрудоспособности».

Если стаж работника составит от 5 Ао 8 мет, то размер пособия по временной потере трудоспособности составит $70 \%$ от начисленной суммы, а именно:

410,95 грн. ${ }^{*} 0,7=287,67$ грн. за счет преАприятия (организации, учреждения);

739,71 грн. * 0,7 = 517,80 грн. за счет Фонда социамьного страхования;

1 150,66 грн. ${ }^{*}$ 0,7 = 805,46 грн. составит общая сумма возмещений по временной потере трудоспособности Аля работника.

Если стаж работника составит от 3 до 3 мет, то размер пособия по временной потере трудоспособности составит $60 \%$ от начисленной суммы, а именно:

410,95 грн. ${ }^{*}$ 0,6 = 246,57 грн. за счет преАприятия (организации, учреждения);

739,71 грн. * 0,6 = 443,83 грн. за счет Фонда социамьного страхования;

1 150,66 грн. ${ }^{*}$ 0,6 = 690,40 грн. составит общая сумма возмещений по временной потере трудоспособности Аля работника.

Если стаж работника составит Ао 3 мет, то размер пособия по временной потере трудоспособности составит $50 \%$ от начисленной суммы, а именно:

410,95 грн. ${ }^{*} 0,5=205,48$ грн. за счет преАприятия (организации, учреждения);

739,71 грн. * 0,5 = 399,86 грн. за счет Фонда социального страхования;

1 150,66 грн. * 0,5 = 575,33 грн. составит общая сумма возмещений по временной потере трудоспособности Аля работника.

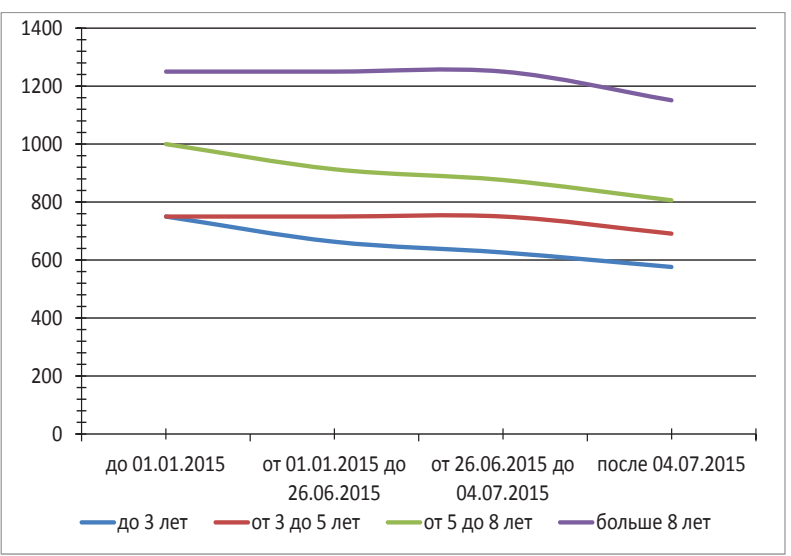

Рис. 2. Анамиз Аинамики размера пособия по временной нетруАоспособности в течение 2015 года
Таблица 6

Анализ размера пособия

по временной нетруАоспособности

\begin{tabular}{|c|c|c|c|c|}
\hline Периоды & Стаж & 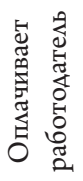 & 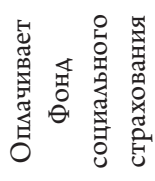 & $\sum_{j}^{\lessgtr}$ \\
\hline \multirow{4}{*}{ Aо 01.01.2015 } & Ао 3 мет & 225 & 525 & 750 \\
\hline & От 3 Ао 5 мет & 225 & 525 & 750 \\
\hline & От 5 Ао мет & 300 & 700 & 1000 \\
\hline & Больше 8 мет & 375 & 875 & 1250 \\
\hline \multirow{4}{*}{$\begin{array}{l}\text { от 01.01.2015 } \\
\text { до 26.06.2015 }\end{array}$} & Aо 3 кет & 225 & 438 & 663 \\
\hline & От 3 Ао 5 мет & 225 & 525 & 750 \\
\hline & От 5 до мет & 300 & 613 & 913 \\
\hline & Больше 8 мет & 375 & 875 & 1250 \\
\hline \multirow{4}{*}{$\begin{array}{l}\text { от 26.06.2015 } \\
\text { Ао04.07.2015 }\end{array}$} & Aо 3 нет & 188 & 438 & 626 \\
\hline & От 3 Ао 5 мет & 225 & 525 & 750 \\
\hline & От 5 Ао мет & 263 & 613 & 876 \\
\hline & Больше 8 мет & 375 & 875 & 1250 \\
\hline \multirow{4}{*}{ от 04.07.2015 } & Ао 3 кет & 206 & 370 & 576 \\
\hline & От 3 до 5 мет & 247 & 444 & 691 \\
\hline & От 5 до мет & 288 & 518 & 806 \\
\hline & Больше 8 мет & 411 & 740 & 1151 \\
\hline
\end{tabular}

5. Сравнение Аинамики размера пособия по временной нетруАоспособности Ао и после изменений от 04.07.2015

Результаты нашего исследования отобразим в таблице 6 «Анализ размера пособия по временной нетрудоспособности».

Отобразим наши расчеты схематично с помощью графика, изображена на рисунке 2 «Анализ динамики размера пособия по временной нетрудоспособности в течение 2015 года».

\section{6. Анализ причин и послеАствий изменений законоАатемьства по социамьному страхованию}

Из графика видно, что уровень пособия по временной нетрудоспособности при расчете по новым законодательным нормам уменьшится. Можно выделить несколько причин внеАрения таких законодательных норм:

1. Приближение к полному реформированию системы социального страхования по предоставмению материального обеспечения.

2. Упрощение процедуры расчета пособия по временной нетрудоспособности.

3. Уменьшение ошибок при начислении социальных выпиат.

4. Прозрачность и понятность начисления пособия Аля застрахованных миц.

5. Большая правдивость отображения информации в бухгалтерском учете.

6. Экономия средств Фонаа.

7. Переход к европейским стандартам. 
Относительно Аальнейших изменений системы социацьного страхования, то есть Ава возможных направмения развития. С одной стороны пианируется перевести обязанности по расчету и начислению еАиного социального взноса на ФонА социального страхования. ОАнако, процедура осуществмения финансирования вЫГАЯАИт АОвольно сложно.

ФонА социального страхования, осуществляя обмен Аанными с Пенсионным Фондом и имея доступ к единой базе Аистков нетрудоспособности, мог бы постепенно финансировать кажАый скучай нетрудоспособности по мере его наступиения. СреАства в таком случае следовало бы перечислить на карточные счета работников по преАставлению работодателей при составлении персонифицированной отчетности в органы Пенсионного Фонда Украины. ОАнако такая система могла бы иметь большое количество змоупотреблений и требует Аостаточно большого штата работников социального страхования, на содержание которого значительно возрастут расходы Фонда. Есть проблемы с учетом стажа работников, с актуальностью счетов мичных карт, а также с урегулированием оплаты первых 5 дней нетрудоспособности.

С Аругой стороны осуществлять регистрацию и оплату больничных мистов можно в электронном виде по преАставлению организаций. В сегодняшних условиях это было бы самым простым и самым оптимальным решением. ОАнако, существует проблема с обратной связью со страхователями, с большим количеством ошибок, которые работники бухгалтерии часто допускают при начисмения материамьного обеспечения по временной потере трудоспособности.

Также речь идет о уменьшение функций Фонда социального страхования и внедрение страховой меАицины. Оплата первых 12 календарных дней будет осуществляться за счет организации, а в последующие Ани нетрудоспособности (при необходимости), - за счет перехода на страховую медицину. Тем самым удержания единого взноса и налогов с заработной платы или пособия по временной нетрудоспособности, будет отменен. Работодатели будут платить только начисления на фонА оплаты труаа и больничных выплат.

Четких шагов по широкому внеАрению страховой медицины в сферу социального страхования в Украине еще нет, а основные моменты функционирования такой системы потребует исслеАования и разработки.

\section{7. Вероятный путь Аамьнейшего реформирования системы \\ социального страхования в Украине}

Сейчас предлагается реформирования системы социального страхования путем увеличения обязанностей работодателя по обеспечению оплаты временной нетрудоспособности.

Основными моментами такого подхода явцяются: 1. Уменьшение функций Фонда социального страхования (что позволит значительно снизить затраты среАств государственного бюАжета).
2. 12 календарных дней нетрудоспособности финансирует работодатень.

3. Неработоспособность более 12 Аней - средства, накопленные на личном счете застрахованного мица, которые можно использовать только в цемях улучшения зАоровья.

4. Аистья нетрудоспособности - бланк строгой отчетности, как основание Аля выплаты помощи.

5. Невыясненными остаются вопросы удержания единого взноса, налога с Аохода физических миц, начисления на фонА оплаты труда, вопросы учета стажа при определении размера помощи.

Рассмотрим возможный процесс начисления материамьного обеспечения с учетом описанных изменений по реформированию системы социального страхования.

Сотрудник организации получает ежемесячно 2500 грн. в течение послеАних 12 месяцев. ПериоА отпуска был в июле 2015 года. Работник отсутствовац на рабочем месте в связи с болезнью с 10 по 20 августа. С работником произошел страховой случай 10 октября. Ему выдали мисток нетрудоспособности сроком на 15 Аней - с 10 по 25 октября. 27 октября он обратился с Аистком нетрудоспособности в бухгалтерию. Рассчитаем размер пособия, причитающегося работнику за такой периоА нетрудоспособности.

1. Первые 12 Аней нетрудоспособности работнику оплатит работодатель. В таблице 7 «асчет среднеАневной заработной платы Аля работника» приведем Аанные Аля расчета среАнеАневной заработной платы за календарные Ани.

Таблица 7

Расчет среднедневной заработной пматы Амя работника

\begin{tabular}{|l|c|c|}
\hline Месяц & $\begin{array}{c}\text { ОклаА (согласно } \\
\text { отработанному времени), } \\
\text { грн. }\end{array}$ & $\begin{array}{c}\text { Количество } \\
\text { календарных } \\
\text { Аней }\end{array}$ \\
\hline Август & 2500 & 30 \\
\hline Июль & 1693,55 & 21 \\
\hline Июнь & 2500 & 31 \\
\hline Май & 2500 & 30 \\
\hline Апремь & 2500 & 31 \\
\hline Март & 2500 & 30 \\
\hline Феврамь & 2500 & 31 \\
\hline Январь & 2500 & 28 \\
\hline Аекабрь & 2500 & 31 \\
\hline Ноябрь & 2500 & 31 \\
\hline Октябрь & 2500 & 30 \\
\hline Сентябрь & 2500 & 31 \\
\hline СуММА & 29193,55 & 355 \\
\hline
\end{tabular}

Рассчитываем среднедневная заработная пиата: $29193,55 / 355=82,24$

2. Теперь определим размер помощи за весь периоА нетрудоспособности. Амя этого нужно размер среАнеАневной зарплаты умножить на количество календарных Аней в периоде нетрудоспособности. Первые 12 кален- 
Аарных дней оплачиваются за счет среАств преАприятия (организации, учреждения). Размер помощи за весь периоА нетрудоспособности составит:

82,24 грн. * 12 камендарных Аня $=986,88$

ПреАположим, что коэффициент стажа на время расчета размера материального обеспечения составмяет $100 \%$; работник отработал более 8 мет или коэффициент стажа больше не применяется. Отразим эти операции на счетах бухгалтерского учета - таблица 8 «Корреспонденция счетов по начислению пособия по временной нетрудоспособности».

\section{Таблица 8}

Корреспонденция счетов по начислению пособия по временной нетруАоспособности

\begin{tabular}{|c|l|c|c|c|}
\hline № & \multicolumn{1}{|c|}{ Бухгалтерская операция } & $\mathrm{AT}$ & Кт & Сумма \\
\hline 1. & $\begin{array}{l}\text { Начисление пособия за счёт } \\
\text { работодателя }\end{array}$ & 93 & 663 & 986,88 \\
\hline 2. & $\begin{array}{l}\text { Начисление единого социального } \\
\text { взноса (20\%) }\end{array}$ & 663 & 651 & 197,38 \\
\hline 3. & Начисление налога с дохода (20\%) & 663 & 651 & 197,38 \\
\hline 4. & $\begin{array}{l}\text { Выплачено с кассы пособие за счёт } \\
\text { работодателя }\end{array}$ & 301 & 663 & 986,88 \\
\hline
\end{tabular}

\section{8. ВЫвоАЫ из провеАеННого исслеАОваНИЯ}

Таким образом, исследования вмияния законодательных изменений на процесс расчета пособия по временной потере трудоспособности с помощью детального рассмотрения процесса расчета, начисления и отражения таких бухгалтерских операций в учете позволило провести анализ влияния изменений законодательных актов в сфере социального страхования на размер возмещенного материальной помощи. Уменьшение процентов выплаты материальной помощи в зависимости от страхового стажа обусловило уменьшение сумм, подлежащих возмещению наемным работникам за счет Фонда социального страхования, а позже - и за счет работодателя.

Введение процесса начисления материальной помощи в календарных Анях обусловило облегчения процесса расчета суммы пособия по временной потере трудоспособности, уменьшение расходов среАств Фонда. Реформирование системы социального страхования в Украине продолжается. В ближайшее время будут введены новые изменения к становлению целостности и оптимальности процессов социального страхования в Украине. Исследования в этой области были и остаются актуальными и необходимыми.

\section{References}

Law of Ukraine „About educational state social security” from 23 September. 1999 №439; [Electronic source] Access mode: http://www.zakon.rada.gov.ua

According to Cabinet of Ministers of Ukraine Enactment from 26.06.2015 №439 it were made alteration in Cabinet of Ministers of Ukraine Enactment „About calculation of average wages (profit, cash security) for enumeration of average paid to educational state social security. № 1266 from 26.09.2001; [Electronic source] - Access mode: http://www.zakon.rada.gov.ua

\section{Янина НИКИТИНА}

\section{ОСОБЕННОСТИ НАЧИСЛЕНИЯ И ОТРАЖЕНИЯ В УЧЁТЕ ПОСОБИЯ ПО ВРЕМЕННОЙ ПОТЕРЕ ТРУДОСПОСОБНОСТИ В 2015 ГОДУ И ПЕРСПЕКТИВЫ ДАЛЬНЕЙШЕГО РЕФОРМИРОВАНИЯ СФЕРЫ СОЦИАЛЬНОГО СТРАХОВАНИЯ В УКРАИНЕ}

Аннотация. Цель работы заключается в том, чтобы исследовать влияние законодательных изменений на процесс расчета пособия по временной потере трудоспособности и отражения таких операций на счетах бухгалтерского учета, с целью прогнозирования будущих направлений развития и становления системы социального страхования по временной потере трудоспособности в Украине. Метод анализа данных о размере материального обеспечения при временной потере трудоспособности с учетом влияния различных законодательных условий позволил исследовать последствия введения тех или иных нормативных актов. Методика исследования осуществляется путем сравнения размера материального возмещения при наступлении страхового случая в трех различных законодательно контролируемых условиях, которые менялись в Украине в текущем 2015 году. Полученные результаты представлены с помощью линейного графика. Проанализирована динамика уровня материального обеспечения по временной потере трудоспособности, в связи с изменением порядка расчета такой помощи для каждого отдельного работника. Государственное регулирование пытается минимизировать собственные расходы и в соответствии с этим реформирует учет в социальной сфере. Результаты исследования показывают причины и экономические последствия введения действующих законодательных норм от 04 июля 2015 года и дают возможность спрогнозировать будущие изменения на пути к установлению единых правил реализации социального страхования по временной потере трудоспособности и внедрения медицинского страхования в Украине. Также рассмотрены основные направления возможных реформ в сфере возмещения утраченного заработка. В частности приведен 
пример отражения факта наступления страхового случая и начисления пособия по временной потере трудоспособности с помощью ситуативного примеру. Система социального страхования в Украине сегодня испытывает значительные преобразования с целью ее совершенствования и адаптации к мировым тенденциям. Осуществление бухгалтерского учета различных участков и сфер деятельности претерпевает постоянные изменения на пути к оптимизации, обеспечения соответствия основным принципам бухгалтерского учета, более полного отражения и фиксирования бухгалтерских событий, системности и понятности регистрации учётных данных, прозрачности и упрощения вычислений и начисления различных бухгалтерских показателей. Практическое значение проведенного исследования заключается в детальном описании процесса начисления материальной помощи по временной потере трудоспособности для застрахованных лиц, в зависимости от стажа наемного работника, и отображения полученных сумм денежных средств на счетах бухгалтерского учета в различных периодах 2015 года. Значение/оригинальность. Полученные результаты данного исследования позволяют структурировать бухгалтерскую информацию относительно процесса начисления пособия по временной потере трудоспособности и создать основу для дальнейших исследований и продолжение реформирования сферы социального страхования в Украине, в соответствии с предложенными направлениями. 